\title{
The Impact of M\&A Announcement and Financing Strategy on Stock Returns: Evidence from BRICKS Markets
}

\author{
Sanjay Sehgal ${ }^{1}$, Siddhartha Banerjee ${ }^{2} \&$ Florent Deisting $^{3}$ \\ ${ }^{1}$ Professor, Department of Financial Studies, University of Delhi, India \\ ${ }^{2}$ Faculty of Management Studies, University of Delhi, India \\ ${ }^{3}$ Professor, ESC-PAU, France \\ Correspondence: Sanjay Sehgal, Professor, Department of Financial Studies, University of Delhi, India. E-mail: \\ sanjay15@gmail.com
}

Received: February 12, 2012

Accepted: September 7, $2012 \quad$ Online Published: October 10, 2012

doi:10.5539/ijef.v4n11p76

URL: http://dx.doi.org/10.5539/ijef.v4n11p76

\begin{abstract}
In this paper, we examine if M\&A announcements and methods of financing these deals affect stock returns. Data is used for BRICKS from the period 2005-2009 and standard event study methodology is used for this purpose. We find significant pre-event returns for 5 out of 6 sample countries. This indicates possible leakages in the information system, which may not be surprising, given the emerging nature of these markets. Three of the BRICKS countries, i.e. India, South Korea and China provide significantly negative post-event returns while strong positive returns are observed in case of South Africa. The extra normal post-event returns defy semi-strong efficiency for majority of sample markets. We further find that M\&A announcements do not significantly alter the trading liquidity and pricing efficiency of the sample stocks. However, return volatility does decline on post event basis. It is also observed that while stock financed mergers are value creating, cash financed mergers seem to be value destroying in the short run. The study is extremely relevant for common shareholders, global fund managers as well as financial regulators. The present research contributes to corporate restructuring as well as market efficiency literature, especially for emerging markets.
\end{abstract}

Keywords: mergers and acquisitions, market model, event study analysis, emerging markets, investment financing strategy

JEL Codes: G14, C12, C13

\section{Introducation}

Corporate restructuring refers to a broad array of activities that expand or contract a company's operations or substantially modify its financial structure or bring about a significant change in its organizational structure and internal financing. It includes activities such as merger, acquisition, de merger, divestiture, slump sale, spin off, equity carve outs etc. However, for the purpose of this study a Corporate Restructuring Event is operationally defined as a merger or an acquisition (hereinafter referred to as M\&As).

Globally, BRICKS nations hold a preeminent position amongst emerging economies. The acronym 'BRIC economies' was coined in a Goldman Sachs report titled "The World Needs Better Economic BRICs" by Jim O'Neill. It highlighted the growing importance of Brazil, Russia, India and China in the world economy, they being the new frontiers of capitalism. The popularity of the Goldman Sachs thesis "BRIC" which even helped inflows of foreign investment into these markets, has led to its extension. "BRICK"(K for South Korea), "BRIMC"(M for Mexico) are some other commonly discussed groups. South Africa expressed a keen interest in being part of the BRIC club and subsequently got an invitation to join the 2011 BRIC nations' summit in China. Hence, we feel that BRICKS (including South Korea and South Africa) becomes an important and diverse group, to necessitate a study that will interest global investors.

A major research approach assessing corporate restructuring events is the value effect (short and long term) of the announcement of restructuring. Typical findings from early studies suggest that M\&As did not enhance firm value, either in the short-run (Dodd, 1980; Asquith, 1983; Malatesta, 1983; Jarrell \&Poulsen, 1989) or in the long-run (Asquith, 1983; Agrawal, Jaffe, \&Mandelker, 1992; Loderer\& Martin, 1992). More specifically, acquisitions were often found to erode acquiring firm value (Chatterjee, 1992; Datta, Pinches, \& Narayanan, 
1992; Seth, Song, \& Pettit, 2002; King, Dalton, Daily, \&Covin, 2004; Moeller, Schlingemann, \&Stulz, 2004) and produce highly volatile stock returns (Langetieg, Haugen, \&Wichern, 1980; Pablo, Sitkin, \& Jemison, 1996).As limited work is available regarding corporate restructuring events in India and other BRICKS nations, and their effects on shareholders' value, there is a felt need for a comprehensive study on the subject for these countries. Moreover, corporate restructuring is an interdisciplinary area of study due to its linkages with corporate finance, investment management as well as behavioral aspects particularly in the context of M\&As.

The present study attempts to fill this important void in M\&A literature. We specifically examine the following propositions for acquirer/ parent companies: 1) Corporate restructuring event generates significantly abnormal returns around the announcement date (i.e. in the short run). 2) Corporate restructuring event significantly changes stock trading volume, volatility of returns and pricing efficiency, from pre to post event periods around the announcement date. 3) Mode of financing M\&A deals substantially affects the post event abnormal stock returns. The outcome of the study will be useful to policy makers for regulation, companies planning restructuring event, corporate finance managers, consultants as well as existing and prospective shareholders.

We find significant pre-event returns for 5 out of 6 sample countries, which may be caused by possible leakages in information. Three of the BRICKS countries, i.e. India, South Korea and China exhibit significantly negative post-event returns while strong positive returns are observed in case of South Africa. The extra normal post-event returns defy semi-strong efficiency for majority of sample markets. It is further found that M\&A announcements do not significantly alter the trading liquidity and pricing efficiency of the sample stocks. However, return volatility does decline on post event basis, which can possibly be explained by arguments provided by Bharath and $\mathrm{Wu}$ (2005). We also find that while stock financed mergers are value creating, cash financed mergers seem to be value destroying in the short run.

The paper is organized into 6 sections, including the present one. Section 2 provides a survey of literature on the subject. Section 3 describes data and their sources, while section 4 deals with methodological issues. In section 5, we discuss empirical results while summary and concluding remarks are contained in the last section.

\section{Review of Literature}

In this section, we provide a survey of literature for both developed and emerging markets.

\subsection{Developed Markets}

A large number of studies, especially in US and UK, have examined the effects of corporate restructuring events on stock returns in the short run, value creation effect in the long run, changes in company characteristics such as stock liquidity and volatility, pre and post restructuring performance and financing aspects relating to M\&As. Some important studies are reviewed in this section.

Keown and Pinkerton (1981) document strong evidence of excess returns earned by investors in target companies prior to the public announcement of mergers. They argued that abnormal price movement can be construed as evidence that the market reacted to the information ahead of its public announcement.

Travlos (1987) explores the role of the method of payment in explaining common stock returns of bidding firms at the announcement of takeover bids. The results reveal significant differences in the abnormal returns between common stock offers and cash offers. The results are independent of the type of takeover bid, i.e., merger or tender offer, and of bid outcomes. These findings, supported by analysis of nonconvertible bonds, are attributed mainly to signaling effects and imply that the inconclusive evidence of earlier studies on takeovers may be due to their failure to control for the method of payment.

Franks, Harris and Titman (1991) investigate share-price performance following corporate takeovers. They use multifactor benchmarks from the portfolio evaluation literature that overcome some of the known mean-variance inefficiencies of more traditional single-factor benchmarks. Studying 399 U.S. takeovers consummated in the 1975-1984 period, they conclude that previous findings of poor performance after takeover are likely due to benchmark errors rather than mispricing at the time of the takeover.

Schaik and Steenbeek (2004) study 136 domestic mergers between non-financial companies in Japan between 1993 and 2003. Consistent with other findings, and in contrast to US evidence, bidders show a positive abnormal return around the announcement date of approximately $1.4 \%$. The largest return is being realized in the 2 days before the announcement, but gains are quickly lost thereafter. Interestingly, trading volume appears to increase after the announcement. Announcement returns are found to be related to the presence of a common shareholder holding shares in both the bidder and the target company and whether the deal took place after 1997. They further find relationship between the size of the target company relative to the bidder company and the volume effect. 
Alexandridis, Petmezas and Travlos (2010) use observations from US, UK and Canadian firms relating public acquisitions and find that they generate, at best, zero abnormal returns, and their stock financed subset negative abnormal returns for acquiring firms around the deal announcement. However, in other markets, which are deemed to be less competitive, the acquirers pay lower premia and realize gains, while share-for-share offers are at least non-value destroying for their shareholders.

\subsection{Emerging Markets}

Anson Wong, Kui Yin Cheung (2009) study the effects of corporate restructuring announcements on the pricing behavior of the Asian acquirer and target firms using the Bloomberg Database and Reuters Business Database. The markets studied were Hong Kong, China, Taiwan, Singapore, South Korea and Japan over the period from 1 January 2000 to 31 December 2007. Their results indicate that bidding firms see upside whereas target firms suffer from the downsides. Moreover, they find that the abnormal return for the shareholders of bidding firms during the post-announcement period depends on the type of acquisition.

Ma, Jianyu,Pagán, José A,Chu, Yun (2009) investigate the abnormal stock price returns of bidder firms around the day of M\&A announcement for 10 emerging Asian markets: China, India, Hong Kong, Indonesia, Malaysia, the Philippines, Singapore, South Korea, Taiwan and Thailand. With a sample of 1,477 M\&A deals, they found expected positive cumulative abnormal returns in 3 different event windows: a two-day $(0,1)$ window, a three-day $(-1,+1)$ window, and a five-day $(-2,+2)$ window. Valuation effects of information leakage about M\&A deals were concluded to be statistically significant.

In India the empirical literature on the subject is limited and of recent origin.

Pandey (2001) examines the issue of takeover announcements, open offers and their impact on shareholders' value in the Indian corporate sector. Based on an empirical investigation of 14 large takeover related open offers, using event study methodology, he documented significant announcement effect $(10 \%)$ associated with the takeovers in the Indian capital market. He also found that target firm valuations increase in the short run up to announcement.

Dash (2004) examines the economic consequences of mergers with a view of resolving the conflict. It is found that modern mergers are primarily motivated by the firms with above industry-average performance and this trend continues to persist over the time. The event study methodology employed to assess the extent of value creation by mergers during 1994-96, indicates that on an average, mergers lead to value destruction and destruction of value is greater in case of unrelated mergers.

Sehgal, Sangh and Choudhary (2005) examined the data from 31 Indian corporate restructuring events and found the existence of pre-event extra normal profits and leakage of information. In the post-event phase, the evidence was mixed, with only 'Change in Management' type events leading to significant gains.

Suresh, Thenmozhi and Vijayaraghavan (2006) conducted a study to see the stock market's impact to 25 public announcements of both internal and external strategic decisions of Indian companies during January1, 2004 to May 31, 2005. The study concluded that the market penalized merger announcements substantially as the abnormal returns were negative, though not significantly different from zero on the days surrounding the event. The group means of the post announcement period were substantially lower than the means of the pre-announcement period, reflecting erosion in the firm value.

Anand and Singh (2008) analyzed short term shareholder wealth effects of the Indian bank mergers during the period 1999 to 2005. Event study methodology has been used to assess the impact on the firm's stock prices. The results document positive and significant increase in value to the shareholders of bidder banks, target banks and their combined portfolio.

\section{Data}

We consider the M\&As completed during the period January 01, 2005 to December 31, 2009. The Thomson One online databases, along with the Thomson Reuters Spreadsheet Link (TRSL), were used for acquiring the data. The list of M\&As were extracted from the online Thomson One database. Names and SEDOLs of acquirers were searched and matching Thomson Tickers were found, so that daily data could be extracted from TRSL. This gave us a complete dataset for 237 out of the initial 458 companies, from which again duplicates (a single day's transaction listed multiple times due to purchase in tranches) were removed to arrive at the final list of 214 companies.

For the 214 acquirer companies studied, both the acquirer and target companies were publicly listed in Brazil, Russia, India, China, South Korea and South Africa. Cross border M\&A cases were not included. Only 
transactions where the percentage of shares acquired was more than $15 \%$ were considered. This was to ensure that the effects of substantial acquisitions were studied. Other criterion for company selection was the availability of daily stock prices for 141 days, involving a 100 day estimation window (T0-120-T0-21 days), 20 days pre-event window (T0-20-T0-1 days), event date (Day T0) and 20 day post event window (T0+1-T0+20 days). We obtain this information by screening the companies over $\mathrm{T} 0-150$ to $\mathrm{T} 0+50$ observation window, owing to missing price observations. Data details for the sample countries are given in table 1.Our data set looks skewed with South Korea and India accounting for about $50 \%$ and $20 \%$ respectively of the sample companies. The missing data is the reason for the variation in the number of companies studied from each country. We used an internationally acceptable financial database and hence, have to adhere with data limitations. However, one has to be extremely careful while drawing general interpretations, given the unbalanced nature of our dataset.

For the next part of the study that deals with the impact of M\&A announcement on stock characteristics, daily trading volumes 20 days prior and post the M\&A announcement were additionally obtained. Volume data could be obtained for a list of 211 out of the 214 sample companies described previously. A screening window of T0-50 to T0+50 days was used to get data on account of missing observations, from which 20 pre and post data points were extracted. For the final part of the study, we obtain details of mode of financing (Cash, Debt and Stock considerations) for these M\&A deals. Such information is available for only 116 out of the 214 sample companies. Owing to this relatively small sample size, we do not perform country specific analysis while evaluating the relationship between mode of financing and post event stock returns.

For finding the abnormal returns, we benchmark the returns on sample companies against stock indices from the same sample countries. The indices used are: IBOVESPA Brazil Index, RUSSIA RTS, BSE National 500, Shanghai SE Composite Index, KOSPI Composite Index, FTSE/JSE Allshare. The list of indices and their details are given in table 2. Daily data is collected for each of the stock market indices for the corresponding periods.

We also classify the sample companies based on Standard Industry Classification system, obtained from Thomson Reuters Spreadsheet Link (TRSL). SIC is a classification system that employs four-digit code and is extensively used this purpose in contemporary research.

\section{Methodology}

Event study methodology, as developed by Fama, Fisher, Jensen and Roll (1969)and Brown and Warner (1985), is ideal for discerning the influence of particular events on shareholder wealth. The event date labeled ' $\mathrm{T} 0$ ' is the date of announcement of the corporate restructuring. We use the daily closing stock prices for the period T0-120 days to $\mathrm{T} 0+120$ days. This daily price series is converted into daily return series using the formula:

$$
R_{i, t}=\log _{e}\left(P_{i, t} / P_{i, t-1}\right)
$$

where $R_{i, t}$ is the return on Day $t$ for the stock $i, P_{i, t}$ and $P_{i, t-1}$ are the closing prices on days $t$ and $t-1$ respectively of the stock i.Daily returns were found for the various country specific indices described in the previous section for the same period. Next, we use the market model (Sharpe, 1963) which relates the return of a security to the return of the market index as shown:

$$
R_{i, t}=\alpha_{i}+\beta_{i} R_{m, t}+\varepsilon_{i, t}
$$

(where $\mathrm{E}\left[\varepsilon_{\mathrm{i}, \mathrm{t}}\right]=0$ and $\operatorname{Var}\left[\varepsilon_{\mathrm{i}, \mathrm{t}}\right]=\sigma_{\mathrm{ei}}^{2}$ )

where $R_{i, t}$ and $R_{m, t}$ are the Day $t$ returns on security $i$ and the market index, (e.g. BSE 500), respectively. $\varepsilon_{i, t}$ is the zero mean error term and $\alpha_{i}, \beta_{i}$ and $\sigma^{2}{ }_{\varepsilon i}$ are the estimated parameters of the market model.

The market model is estimated using Ordinary least squares (OLS) regression. The estimation window is a rolling window comprising of 100 days immediately before the day $t$, on which the return $\mathrm{R}_{\mathrm{i}, \mathrm{t}}$ is to be computed. This procedure helps us in obtaining dynamic values of $\alpha_{i}$ and $\beta$, which change for each day of our event window ( -20 to +20 days) and allow us to obtain more precise values of expected returns for each day of event window. $1^{\text {st }}$ order autocorrelation is checked for in the error term using Ljung-Box-Pierce Q-test. In case autocorrelation is detected at 5\% significance level, the GLS estimation procedure is adopted to ensure efficiency of the estimated parameters. The period consisting of day T0-120 to day T0-21 was used to obtain the initial estimates of $\alpha_{i}, \beta_{i}$ and the process is repeated by skipping one day at a time.

Next, we define abnormal return as:

$$
A R_{i, t}=(\text { Actual Return })_{i, t}-(\text { Expected Return })_{i, t}
$$


where (Actual Return $)_{i, t}$ is the realized return of the security $i$ on day $t$ and (Expected Return $)_{i, t}$ is calculated according to equation 2 for $\mathrm{R}_{\mathrm{i}, \text { t }}$.

We find the daily abnormal returns for the pre-event window, days T0-20 to T0-1 and the process is continued for the post event window, i.e. days $\mathrm{T} 0$ to $\mathrm{T} 0+20$. For drawing inferences about the event impact, the abnormal return observations must be aggregated. The aggregation is studied along 2 dimensions: through time and across securities.

We define Cumulative Abnormal Returns for the stocks as:

$$
\begin{aligned}
\mathrm{CAR}_{\mathrm{i}} & =\sum_{t=T 0-20}^{T 0-1} \mathrm{AR}_{\mathrm{i}, \mathrm{t}} \\
\mathrm{CAR}_{\mathrm{j}} & =\sum_{t=0}^{T 0+20} \mathrm{AR}_{\mathrm{i}, \mathrm{t}}
\end{aligned}
$$

whereCAR and $\mathrm{CAR}_{\mathrm{j}}$ are the pre-event and post-event Cumulative Abnormal Returns, respectively.The CAR values are standardized as follows:

$$
\text { Standardized CAR }(\mathrm{SCAR})=\mathrm{CAR} / \mathrm{SE}_{\mathrm{CAR}}
$$

where $\mathrm{SE}_{\mathrm{CAR}}$ is the standard error of $\mathrm{CAR}$ calculated as:

$$
\mathrm{SE}_{\mathrm{CAR}}=\sqrt{n /(n-2)} \sigma
$$

os are the standard deviations of the ARs, for the T0-20 to T0- 1 and T0 to T0+20 periods. $\mathrm{n}=20$ and 21 for the pre-event and post-event windows respectively.

The SCAR values follow t-distribution and hence, compared to t-statistic, at 5\% confidence level, 2-tailed with $(\mathrm{n}-2)$ degrees of freedom. This allows us to find which of the sample companies have significant abnormal returns in the pre-event and post-event windows.

For country analysis, we take the average of Abnormal Returns, day-wise (i.e. T0-20, T0-19,...,T0+20) for all the companies in each country and label this Average Abnormal Return (AAR). The AARs are cumulated for the pre-event and post-event windows to obtain $C A A R_{\mathrm{i}}$ and $\mathrm{CAAR}_{\mathrm{j}}$ respectively. The CAARs are standardized as follows:

$$
\begin{array}{r}
\text { CAAR }_{\mathrm{i}}=\sum_{t=T 0-20}^{T 0-1} \mathrm{AAR}_{\mathrm{i}, \mathrm{t}} \\
\mathrm{CAAR}_{\mathrm{j}}=\sum_{t=T 0}^{T 0+20} \mathrm{AAR}_{\mathrm{i}, \mathrm{t}} \\
\text { Standardized CAAR }=\mathrm{CAAR} / \mathrm{SE}_{\mathrm{CAAR}}
\end{array}
$$

where $\mathrm{SE}_{\mathrm{CAAR}}$ is the standard error of CAAR:

$$
\mathrm{SE}_{\mathrm{CAAR}}=\sqrt{n /(n-2)} \sigma_{\mathrm{p}}
$$

$\sigma_{\mathrm{p}}$ is given by the Markowitz Portfolio formula:

$$
\sigma_{\mathrm{p}}^{2}=\sum_{i=1}^{N} \mathrm{x}_{\mathrm{i}}^{2} \sigma_{\mathrm{i}}^{2}+\sum_{i=1}^{N} \sum_{j \neq i} \sigma_{\mathrm{i}} \sigma_{\mathrm{j}} \rho_{\mathrm{i}, \mathrm{j}} \mathrm{x}_{\mathrm{i}} \mathrm{x}_{\mathrm{j}}
$$

where $\rho_{i j}$ is the correlation coefficient between the returns on assets $i$ and $j$. In our case, $\mathrm{x}_{\mathrm{i}}=\mathrm{x}_{\mathrm{j}}=1 / \mathrm{n}$ (equally weighted), where $n=$ number of sample companies, in the country being considered. The correlation coefficient is taken to be 0 if there is no overlap in the event windows of the $I$ and $j^{\text {th }}$ companies. This accounts for any cross-correlations between the securities.

The SCAAR values follow t-distribution and now compared to t-statistic, at 5\% confidence level, 2-tailed with (n-2) degrees of freedom. This allows us to find significant average abnormal returns in the pre-event and post-event windows. We also perform aggregate market analysis using CAAR methodology. However, in this case, we take the average daily abnormal returns for all the sample companies before proceeding with further estimation. We also calculate the 3 day (T0-1 to T0+1) CAAR, aggregated by country, to see if there are different patterns between a very short term (3 day) and a short term (41 days) event windows. Specifically, we intend to verify if abnormal returns are more pronounced very close to the event date, which cannot be evaluated using the standard 41 days event window.

Next, we examine the impact of M\&A announcement on stock characteristics. We verify if the knowledge of 
event alters the trading activity, return volatility and pricing efficiency of the sample stocks. For testing any changes in trading activity, we consider the data in the event window, T0-20 to T0-1 days and $\mathrm{T} 0$ to $\mathrm{T} 0+20$ days. For these periods, we calculate the daily average of logarithm of trading volume, standard deviation of daily returns and $1^{\text {st }}$ order autocorrelation of daily returns for each of the 211 sample companies.

For evaluating the significance of change in trading volume, we use the two-sample pooled t-test, equal variances, at $5 \%$ significance level.

$$
\begin{gathered}
\mathrm{t}=\left(\bar{x}_{\mathrm{I}}-\bar{x}_{2}\right) / \mathrm{s}_{\mathrm{p}} \sqrt{\left(\frac{1}{n 1}+\frac{1}{n 2}\right)} \\
\mathrm{s}_{\mathrm{p}}{ }^{2}=\left[\left(\mathrm{n}_{1}-1\right) \mathrm{s}_{1}{ }^{2}+\left(\mathrm{n}_{2}-1\right) \mathrm{s}_{2}^{2}\right] /\left(\mathrm{n}_{1}+\mathrm{n}_{2}-2\right) \\
\mathrm{df}=\left(\mathrm{n}_{1}+\mathrm{n}_{2}-2\right)
\end{gathered}
$$

Here the assumptions are that of normal populations (or $\left.n_{1}+n_{2}>40\right)$ and independent observations and that population standard deviations, $\sigma_{1}=\sigma_{2}$ where $\sigma_{1}$ and $\sigma_{2}$ are unknown.

- $n_{1}=$ sample 1 size.

- $n_{2}=$ sample 2 size

- $s_{1}=$ sample 1 standard deviation

- $s_{2}=$ sample 2 standard deviation

For discovering changes in standard deviation of daily returns, we use the two-sample $\mathrm{F}$ test for equality of variances, at $5 \%$ significance level.

$$
\mathrm{F}=\left(\mathrm{s}_{1} / \mathrm{s}_{2}\right) \text {, with } \mathrm{s}_{1}^{2} \geq \mathrm{s}_{2}^{2}
$$

The null hypothesis $\left(\mathrm{H}_{0}\right)$ that there is no significant change in pre-event and post-event standard deviations of average daily returns is rejected for $F>F\left(\alpha / 2, n_{1}-1, n_{2}-1\right)$.

For discerning changes in the lag 1 autocorrelation, which signifies pricing efficiency, we compute the t-statistic for the differences between pre and post event autocorrelation coefficients.

$$
\mathrm{t}=\left(\mathrm{ACF}_{\mathrm{i}}-\mathrm{ACF}_{\mathrm{j}}\right) / \sqrt{\left(\frac{1}{n 1}+\frac{1}{n 2}\right)}
$$

where $\mathrm{ACF}_{\mathrm{i}}$ and $\mathrm{ACF}_{\mathrm{j}}$ are the pre-event and post-event autocorrelation of daily returns for a 20 days and 21 days periods.

Finally, we evaluate if the mode of financing strategy significantly impacts stock returns. We estimate CAARs after segregating the companies on the basis of investment financing i.e. 1) cash, 2) stock and 3) cash, stock and other modes of financing. We estimate a 20 and 21 days CAARs as well as 3 day CAARs (centered on announcement date). The later shall help us in a better understanding of market reaction very close to the event date, when intensity of trading action is expected to be the highest. The final analysis is performed on aggregate basis, and not on country basis, owing to data limitations discussed in previous section.

\section{Empirical Results}

\subsection{Pre and Post Event Returns}

The pre and post event CAAR values for BRICKS, both on country as well as aggregate basis, are provided in table 3 and depicted in figures $1 \mathrm{a}-1 \mathrm{~g}$. Four out of six sample countries namely Russia, India, China and South Korea report significantly positive abnormal returns on pre-event basis, while pre-event CAAR for Brazil, though positive, is statistically not distinguishable from zero. South African market seems to be an exception, as it provides significantly negative returns for the pre-event period.The CAAR results are also statistically significantly positive on aggregate basis i.e. after accounting for all sample markets.

Extra-normal returns prior to an event maybe caused by 1) superior investment analysis by some of the market participants and/or 2) leakages in information, resulting in insider-trading. Given the pervasiveness of abnormal returns across sample markets and the fact that financial regulation is still evolving in emerging economies, the first argument is relatively less plausible. Hence, our pre-event results possibly point at information leakages and their exploitation by more well informed market traders. These conclusions may not be that farfetched; insider 
trading seems to be prevalent even in mature markets like US, leading to recent investigations by SEC on this issue.

On post event basis, India, China and South Korea provide negative abnormal returns, while positive returns are reported for South Africa. There seems to be a reversal of signs of abnormal returns for these countries while comparing results for pre and post event periods. This clearly points to a change in market sentiment. Pre-announcement, the markets react positively (negatively) to the upcoming M\&A, anticipating it to be value creating (value destroying) for the buyer firms' shareholders. But as the details of the M\&A deal seep in, markets reverse, sensing chances of overpayment (underpayment), which will lead to value destruction (creation) for acquirer firms' shareholders.

Our findings support the overreaction hypothesis and imply that while investors are overoptimistic in India, China and South Korea during the pre-event period, they seem to be over-pessimistic in case of South Africa and correct their behavior after the event. Brazil and Russia do not report any significant post-event CAAR values. On overall basis, strong negative post event abnormal returns are observed for BRICKS. Thus, four out of six sample markets do not seem to be efficient on post-return basis to M\&A announcement. Negative post event CAARs for the acquirers maybe an outcome of market fears of overestimation of synergies by the buyer firms' management and/or overpayment to the seller due to competitive bidding amongst potential acquirers, leaving negative value for the buyer firms' shareholders.

Our results for Chinese and South Korean economies are in contrast with those of Ma, Jianyu, Pagán, José A, \& Chu, Yun (2009). These contradictions may be an outcome of different time periods used by the two studies. It may be recalled that while Ma, et al use a 2000-2007 time period, we employ data from 2005 till 2009. Further, we use a 41 day event window, compared to shorter event windows used by them (Ma, et al use 3 different event windows: a two-day $(0,1)$ window, a three-day $(-1,+1)$ window, and a five-day $(-2,+2)$ window while we primarily study a 41 day $(-20-+20)$ event window). The difference in results point out at significant changes in investor behavior over time in these markets.

We next focus on 3 day CAAR centered at the event date. It can be clearly seen that the 3 day CAAR values account for a major part of abnormal returns, reported over 41 days event window. This confirms that the market reaction is most intense immediately around the event date and most returns (positive or negative) are booked in the immediate vicinity of the event.

Our findings suggest that M\&A announcement information can be exploited by market traders to generate superior profits by aligning their trading strategies for each market i.e. buying for countries that experience post-event positive returns and short-selling for those which report negative return. In case of any short-selling restrictions, they can take trading positions using stock futures. Our results provide support to the M\&A arbitrage strategies used by hedge funds, at least for our emerging market basket.

Next, we perform CAR analysis for individual companies in BRICKS, which is reported in table 4. About $49 \%$ of CAR values are statistically significant both for pre and post event periods on overall basis. $51 \%$ of the significant pre-event CAR values are positive which declines to $44 \%$ for post event analysis. The CAR findings confirm strong abnormal returns prior to the event as well as on post event basis for a large number of cases. South Africa is an exception from the average as $83 \%$ of the significant post event CAR values tend to be positive. In contrast, $70 \%$ of significant post event CAR values in India are negative. Our results suggest possible leakages of M\&A information which is exploited by the market traders on pre event basis for the BRICKS basket. On post event basis, M\&A announcement is relevant for developing trading strategies in general. Specifically, for South Africa and India, long and short positions, respectively may provide abnormal returns.

We also classify individual companies in each country using Standard Industry Classification code discern if there are any sector patterns in post-event returns relating to M\&A announcements. We could not find any clustering of statistically significant CAR values for any specific sector. This implies that abnormal returns are not sector specific and hence knowledge of industry classification may not aid in developing more profitable trading strategies.

\subsection{M\&A Announcement and Stock Characteristics}

We analyze the impact of M\&A announcement on stock characteristics, namely trading liquidity, return volatility and pricing efficiency, the results of which are shown in table 5.

We find that trading liquidity does not change significantly for pre and post event periods for the sample companies. Our results may be justified by the price overreaction hypothesis. We had seen in previous section 
thatstrong positive (negative) pre event CAARs,implying continuation, are followed by significantly negative (positive) post event CAARs, implying reversal. Both continuation and reversal patterns may be supported by trading volumes, which is reflected ininsignificant changes in trading activity for our study. Our findings are in contrast Copeland (1976), Morse (1980 and 1982b), and Verrecchia (1981) who argue that pre-event trading volume should be generally higher owing to asymmetrically distributed information, which creates differences in investors' beliefs.

Next, we examine the volatility of acquirer firms' stock returns around the event date. There are at least three factors that may determine the level of post-merger volatility of the acquirer firms' stock (see SreedharBharath and Guojun $\mathrm{Wu}, 2005)$. First, mergers could be a response to industry shocks faced by firms. Thus, a successful merger may lead to a post-merger decline/stabilization in volatility. Second, one of the most crucial aspects that determines the success or failure of the merger is the ability of acquirer management to unify both the target and acquirer into a single entity after the merger. Thus post-merger integration risk is an important issue that has to be factored in by the financial markets. Based on this argument, we should expect declines/no further increases in volatility with the successful integration of the acquirer and the target, at least in the long run. However, there may be observable short term aberrations in terms of higher post event trading volatility till the time the two companies are fully integrated. Third, the cash flows of the acquirer and the target are imperfectly correlated. Based on the principle of diversification and portfolio theory, we expect acquirers to have declines in volatility immediately after the merger. This decline is likely to be greater for mergers across industries (inter-industry mergers). We find that post event volatility significantly declines compared to pre-event volatility for almost allthe companies in the sample data as shown in table 5. A short-run decrease in price volatility suggests that the diversification benefits outweigh any increase in integration related risks in the short run.

Finally, we check the pricing efficiency of the acquirer firms' stocks around the M\&A announcement date. We observe that most pre and post event abnormal returns are not having autocorrelation at lag 1, implying that there are no pricing inefficiencies. We further confirm that there is no difference in price discovery levels, by comparing the pre and post period autocorrelation values as shown in table 5. This is not surprising given the statistical insignificance of the pre and post event autocorrelation coefficients for the sample companies in the first instance.

\subsection{Mode of Financing and Stock Returns}

In this subsection, we examine the impact of M\&A financing strategy on post announcement stock returns. Previous research agrees that the method of payment plays an important role in explaining acquiring firms' stock returns. However, there are contradictory views as to which mode of financing is value creating (destroying).

Two hypotheses offer a theoretical rationale why the stock financed M\&As should be treated unfavorably by investors: (1) The "information content" hypothesis by Myers and Majluf (1984), predicting that an offer to pay in shares for an acquisition will be seen by market participants as a signal that the stocks are overvalued and (2) the "free cash flow" hypothesis by Jensen (1986), showing that acquisitions being paid for in cash reduce the agency costs of free cash flows. The conclusions of both hypotheses are that stock transactions should lead to negative abnormal returns around the announcement date, whereas cash transactions should result in positive abnormal returns.

Alternative arguments are provided in the literature, that suggest that stock financing should be taken as good news by market traders. There have emerged two alternative hypotheses for explaining acquiring companies' stock return: The Investment Opportunity Hypothesis and the Risk Sharing Hypothesis.

The Investment Opportunity Hypothesis links the existence of growth opportunities with the method of payment for corporate acquisitions. Myers (1977) shows that firms with excellent future investment opportunities are less likely to issue debt than companies with poor future investment opportunities. The reason is that the first group of firms tries to preserve the cash flows to take advantage of the investment opportunities, whereas the second group of firms can use the cash flows for debt service payments without giving away investment opportunities. Similarly, Jung, Kim and Stulz (1996) argue that managers with growth perspectives prefer to raise capital with equity rather than with debt because it gives them more discretion with regard to the future use of the firm's cash flows. The similarities in the decision between how to raise capital and how to pay for corporate acquisitions led Martin (1996) to assume that firms with good investment opportunities prefer to pay in stock for their corporate acquisitions, whereas other firms prefer payment in cash. The Investment Opportunity Hypothesis has been tested by Martin (1996) and the results show that acquiring firms with good future investment opportunities are more likely to offer stock for corporate acquisitions than firms with poor investment opportunities. These results are consistent with the results of the study by Jung/Kim/Stulz (1996), who not only report that firms with 
valuable investment opportunities are more likely to issue equity, but also state that the stock-price reaction to equity issues is more favorable for firms with valuable investment opportunities.

The second hypothesis is the Risk Sharing Hypothesis, and goes back to Hansen (1987). It is strongly related to the asymmetric information problem mentioned by Myers/Majluf (1984), but this time the information asymmetry is not in favor of the acquiring firm. In most acquisitions, the true value of the target firm is difficult to assess and remains controversial even after carefully executed due diligence. Furthermore, it is not necessarily clear to what extent the expected synergies will materialize in the post-acquisition period. The target firm, however, is in most cases fully aware of its true firm value. Hansen (1987) models this situation of asymmetric information between the acquiring firm and the target firm. He concludes that if the bidder is unsure about the true value of the target firm, he will rather offer to pay in stock so that the target firm's shareholder can be forced to share inany post-acquisition revaluation effects. Martin (1996), based on Hansen (1987), also argues that if there is high uncertainty in acquisition outcome, the bidder should rather use stock. Rappaport/Sirower (1999) argue that from a shareholder value point of view, the risk sharing hypothesis should receive high attention: in the case of a pure cash transaction, the post-merger operating risk will exclusively be taken on by the acquiring shareholders. If a risk-adjusted change in shareholder value due to the transaction were to be calculated, this would probably lead to a lower value than compared to a mixed or pure stock transaction.

Thus, the first hypothesis states that firms with excellent future investment opportunities should not pay in cash for acquisitions. Cash transactions often have to be financed with new debt. Cash flows, however, should not be used for debt service payments since this reduces the amount of discretionary cash flows available in the future. The second hypothesis states that, particularly for high-risk transactions, it could be advantageous to pay in stock because in this case, the target company will have an incentive to make a success of the takeover transaction. Both hypotheses predict that stock transactions have no longer to be seen as a negative signal by the market participants and therefore stand in sharp contrast to the hypotheses by Myers/Majluf (1984) and Jensen (1986).

Pre and posts event CAARs of financing strategy based portfolios are provided in table 6 and their graphical depictions are given in figures $2 \mathrm{a}-2 \mathrm{c}$. We do not perform event study analysis separately for each sample country as the matching information for mode of financing and stock returns are available for only a subset of sample companies, i.e., 109 out of 214 firms. Hence, country analysis could suffer from small sample biases in financing strategy based portfolios. On pre event basis, CAARs for cash financed M\&A deals are close to zero, while it is statistically significantly positive for stock and hybrid financing strategies. This may imply possible leakages in information and exploited by inside traders. However our primary focus is on post event performance owing to behavioral implications. We find that while cash based M\&As provide strongly negative CAARs, stock based deals results in significantly positive CAAR values. Our results suggest that choice of payment does affect post-event stock returns and that stock financed deals are perceived to be value creating while cash financed deals are seen as value destroying. These finding are consistent with discussed above.

BRICKS are prominent emerging markets, which exhibit high economic growth rates over the last two decades, generating a plethora of investment opportunity in different sectors. Hence, these companies in the BRICKS basket may prefer to conserve cash for investing in these high growth opportunities by using stock financing as a means for funding inorganic growth through M\&As. Additionally, these emerging markets are still going through economic and financial transition, making them riskier investments. Further, these markets are not fully information efficient and hence, may not generate fair corporate valuations, which may induce the buyer firms to prefer the stock financing mode as this will result in risk sharing with acquired firms' shareholders. Cash based mergers are seen as value destroying by the market as there is a fear of overpayment due to competitive bidding. The payments could be more than the value created by the M\&A. There is a case of asymmetric information between the management of the companies and the external market participants. Hence, the acquirer firm stockholders may fear less value left for them from the merger, with most value accruing to the acquired firm shareholders. This drives the acquirer prices downward. Stock financing mitigates the effect of overvaluation or undervaluation of either firm. With a stock offer, the impending unfavorable news about the acquired firm's value will fall partly on the shoulders of the acquired firm's shareholders. So, the acquiring firm shareholders perceive decreased risk viz.-a-viz. cash acquisitions and react positively. Our results may not be surprising, given the nature of these emerging markets.

Our findings suggest that market traders should pay attention to the choice of payment for M\&A deals, as it has a significant impact on post event returns. Arbitrage strategies can be created by taking long and short positions in the buyers firms in stock and cash financed M\&As respectively. 


\section{Summary and Conclusion}

To conclude, we find significant pre-event abnormal returns for five out of six sample countries. While these pre-event abnormal returns are significantly positive for India, China, Russia and South Korea, they are strongly negative for South Africa. This may point at possible information leakages in the system which has policy implications for financial regulators. On post-event basis, there is reversal in signs of abnormal returns, i.e. India, China and South Korea provide negative profits, while South Africa experiences strong positive returns. Our findings support the overreaction hypothesis and imply that while investors are overoptimistic in India, China and South Korea during the pre-event period, they seem to be over-pessimistic in case of South Africa and correct their behavior after the event.

We further examine the impact of M\&A announcement on stock characteristics. It is found that corporate restructuring event does not significantly alter the trading liquidity of the sample stocks. Our findings are in contrast with Copeland (1976), Morse (1980 and 1982b), and Verrecchia (1981), who argue that pre-event trading volume should be generally higher owing to asymmetrically distributed information, which creates differences in investors' beliefs. It is further shown that return volatility significantly declines for sample stocks when one compares the pre and post event periods. A short-run decrease in price volatility suggests that the diversification benefits from merger outweigh any increase in integration related risks in the short run [For volatility related argument, see Bharath and $\mathrm{Wu},(2005)]$. We also find that pricing efficiency of sample stocks does not alter owing to $M \& A$ announcement.

Finally, we evaluate if mode of M\&A financing affect post event stock returns for buyer companies in the sample countries. It is observed that while stock financed mergers are value creating, cash financed mergers seem to be value destroying in the short run. Our findings are consistent with Investment Opportunity Hypothesis as well as Risk Sharing Hypothesis proposed by Martin (1996).

The study has strong implications for global fund managers. The results suggest that they should pay attention to M\&A announcements and the method of financing deals in emerging markets as such information can be used for developing profitable trading strategies. There are also implications for policy makers. The financial regulators should be concerned about insider trading and price manipulation, and tighten regulations to discourage them.

For future research, we recommend that event study analysis could be performed for target firms from BRICKS nations so that one gets a complete picture. Also, other type of corporate restructuring events, namely spinoffs and divestitures may be looked at as well. Multifactor models like Fama-French (1993) could be used to see if a pattern can be discerned regarding information leakage and any of the factors like market cap or PE valuations.

\section{References}

Agrawal, A., Jaffe, J. F., \& Mandelker, G. N. (1992). The post-merger performance of acquiring firms: A reexamination of an anomaly. Journal of Finance, 47, 1605-1621. http://dx.doi.org/10.1111/j.1540-6261.1992.tb04674.x

Alexandridis, G., Petmezas, D., \& Travlos, N. (2010). Gains from Mergers and Acquisitions around the World: New Evidence. Financial Management, 39, 1671-1695. http://dx.doi.org/10.1111/j.1755-053X.2010.01126.x

Anand, Manoj, \& Singh, Jagandeep. (2008). Impact of Merger Announcements on Shareholders' Wealth: Evidence from Indian Private Sector Banks. Vikalpa, 33(1), 35-54.

Anson Wong, \& Kui Yin Cheung. (2009). The Effects of Merger and Acquisition Announcements on the Security Prices of Bidding Firms and Target Firms in Asia. International Journal of Economics and Finance, 1(2).

Asquith, P. (1983). Merger bids, uncertainty, and stockholder returns. Journal of Financial Economics, 11, 51-83. http://dx.doi.org/10.1016/0304-405X(83)90005-3

Bharath, S. T., \& Guojun Wu. (2005). Long-run volatility and risk around mergers and acquisitions. Working paper, University of Michigan

Brown, S. J., \& Warner, J. B. (1985). Using Daily Stock Returns: The case of event studies. Journal of Financial Economics, 8, 105-138

Chatterjee, S. (1992). Sources of value in takeovers: Synergy or restructuring implications for target and bidder firms. Strategic Management Journal, 13, 267-286. http://dx.doi.org/10.1002/smj.4250130403

Copeland, Thomas E. (1976). A Model of Asset Trading Under the Assumption of Sequential Information Arrival. 
The Journal of Finance, 31(4), 1149-1168. http://dx.doi.org/10.2307/2326280

Dash, A. (2004). Value Creation through Mergers: The Myth and Reality. The ICFAI Journal of Applied Finance, 20-38.

Datta, D. K., Pinches, G. E., \& Narayanan, V. K. (1992). Factors influencing wealth creation from mergers and acquisitions - a meta-analysis. Strategic Management Journal, 13, 67-84. http://dx.doi.org/10.1002/smj.4250130106

Dodd, P. (1980). Merger proposals, management discretion and stockholder wealth. Journal of Financial Economics, 8, 105-137. http://dx.doi.org/10.1016/0304-405X(80)90014-8

Fama, E. L. Fisher, M. Jensen, \& R. Roll. (1969). The adjustment of stock prices to new information. International Economic Review, 10, 1-21. http://dx.doi.org/10.2307/2525569

Fama, E.L., \& French, Kenneth R. (1993).Common risk factors in the returns on stocks and bonds. Journal of Financial Economics, 33(1), 3-56.

Franks, J., Harris, R., \& Titman, S. (1991).The post-merger share-price performance of acquiring firms. Journal of Financial Economics, 29, 81-96. http://dx.doi.org/10.1016/0304-405X(91)90014-B

Hansen, Robert G. (1987). A Theory for the Choice of Exchange Medium in Mergers and Acquisitions. The Journal of Business, 60(1), 75-95. http://dx.doi.org/10.1086/296386

Jarrell, G. A., \& Poulsen, A. B. (1989). The returns to acquiring firms in tender offers: Evidence from 3 decades. Financial Management, 18(3), 12-19. http://dx.doi.org/10.2307/3665645

Jensen, Michael C. (1986).Agency Costs of Free Cash Flow, Corporate Finance, and Takeovers. The American Economic Review, 76(2), 323-329. Papers and Proceedings of the Ninety-Eighth Annual Meeting of the American Economic Association (May).

Keown, A. J., \& Pinkerton, JM (1981). Merger Announcements and Insider Trading Activity: An Empirical Investigation. Journal of Finance, 36, 855-69. http://dx.doi.org/10.1111/j.1540-6261.1981.tb04888.x

King, D. R., Dalton, D. R., Daily, C. M., \& Covin, J. G. (2004). Meta-analyses of post-acquisition performance: Indications of unidentified moderators. Strategic Management Journal, 25, 187-200. http://dx.doi.org/10.1002/smj.371

Kooyul Jung, Yong-Cheol Kim, \& Rene M. Stulz. (1996). Timing, investment opportunities, managerial discretion, and the security issue decision. Journal of Financial Economics, 42(2), 159-186. http://dx.doi.org/10.1016/0304-405X(96)00881-1

Langetieg, T. C., Haugen, R. A., \& Wichern, D. W. (1980). Merger and stockholder risk. Journal of Financial and Quantitative Analysis, 15, 689-717. http://dx.doi.org/10.2307/2330404

Loderer, C., \& Martin, K. (1992). Post-acquisition performance of acquiring firms. Financial Management, 21(3), 69-79. http://dx.doi.org/10.2307/3666020

Ma, Jianyu, Pagan, Jose A., \& Chu, Yun. (2009).Abnormal returns to mergers and acquisitions in ten Asian stock markets.The Free Library. Retrieved December 12, 2010 from: http://www.thefreelibrary.com/Abnormal\%20returns\%20to\%20mergers\%20and $\% 20$ acquisitions $\% 20 \mathrm{in} \% 20 \mathrm{t}$ en\%20Asian\%20stock\%20...-a0204209480.

Malatesta, P. H. (1983). The wealth effect of merger activity and the objective functions of emerging firms. Journal of Financial Economics, 11, 155-181. http://dx.doi.org/10.1016/0304-405X(83)90009-0

Martin, Kenneth J. (1996). The Method of Payment in Corporate Acquisitions, Investment Opportunities, and

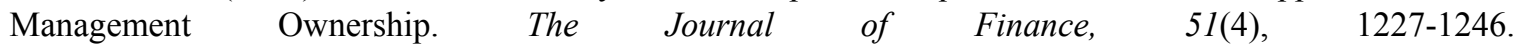
http://dx.doi.org/10.1111/j.1540-6261.1996.tb04068.x

Moeller S. B, Schlingermann F. P., \& Stulz R. M. (2004). Firm Size and the Gains from Acquisitions. Journal of Financial Economics, 73(2), 201-28. http://dx.doi.org/10.1016/j.jfineco.2003.07.002

Morse, Dale. (1980). Asymmetrical Information in Securities Markets and Trading Volume. Journal of Financial and Quantitative Analysis, 15, 1129-1148. http://dx.doi.org/10.2307/2330176

Morse, Dale. (1982). Wall Street Journal Announcements and the Securities Markets. Financial Analysts Journal, 38(2), 69-76.

Myers, Stewart C. (1977). Determinants of corporate borrowing. Journal of Financial Economics, 5(2), 147-175. 
http://dx.doi.org/10.1016/0304-405X(77)90015-0

Myers, Stewart C., \& Majluf, Nicholas S. (1984). Corporate Financing and Investment Decisions when Firms Have Informationthat Investors Do Not Have. NBER Working Paper Series, w1396.

Pablo, A. L., Sitkin, S. B., \& Jemison, D. B. (1996). Acquisition decision-making processes: The central role of risk. Journal of Management, 22, 723-746. http://dx.doi.org/10.1177/014920639602200503

Pandey, A. (2001). Takeover Announcements, Open Offers and Shareholders' Returns in Target Firms. Vikalpa, 26(3), 19-30.

Rappaport A., \& Sirower ML. (1999). Stock or cash? The trade-offs for buyers and sellers in mergers and acquisitions. Harvard Business Rev., 77(6), 147-58, 217.

Schaik, Dimitri V., \& Steenbeek, Onno W. (2004). Price and Volume Effects of Merger Bids in Japan. vailable at SSRN:http://ssrn.com/abstract $=592081$.

Sehgal, S., Singh, A., \& oudhary, A. (2005). The Relationship between corporate takeovers and share prices for the target firms: Evidence for the Indian stock market. Journal of Accountig, Business and Management, 12, 171-186.

Seth, A., Song, K. P., \& Pettit, R. R. (2002). Value creation and destruction in cross-border acquisitions: An empirical analysis of foreign acquisitions of US firms. Strategic Management Journal, 23, 921-940. http://dx.doi.org/10.1002/smj.264

Sharpe, William F. (1963). A Simplified Model for Portfolio Analysis. Management Science, 9(2), 277-293 http://dx.doi.org/10.1287/mnsc.9.2.277

Srinivasan, S., Thenmozhi, M., \& Vijayaraghavan, P. (2006). Impact of diversification Strategy on Firm Performance: Entropy Approach. ICFAI Journal of Applied Finance, 12(11), 27-48.

Travlos, N. G. (1987). Corporate takeover bids, methods of payment, and bidding firms stock returns. Journal of Finance, 42, 943-963. http://dx.doi.org/10.1111/j.1540-6261.1987.tb03921.x

Verrecchia, R. E. (1980). Consensus beliefs, information acquisition, and market efficiency. American Economic Review, 70, 874-884.

\section{Appendix}

Table 1. Criteria for data selection

\begin{tabular}{ll}
\hline Countries from & Brazil, Russia, India, China, South Korea, South Africa \\
\hline Acquirer and acquired status & Public \\
Date of Announcement & $01 / 01 / 2005$ to $12 / 31 / 2009$ \\
\% of Shares Acquired in Transaction & $15 \%-100 \%$ \\
Deal Status & Completed \\
Data window used & -150 days- +150 days data used to get $-120-+120$ days data points \\
& around event date, accounting for missing data \\
Number of companies & 214 (Phase 1), 211 (Phase 2), 116 (Phase 3) \\
\hline
\end{tabular}

Table 2. Summary of Stock Market Indices used in the study for the sample countries

\begin{tabular}{|c|c|c|c|c|c|c|}
\hline Index Name & $\begin{array}{l}\text { IBOVESPA } \\
\text { Brazil Index }\end{array}$ & $\begin{array}{l}\text { RUSSIA } \\
\text { RTS }\end{array}$ & $\begin{array}{l}\text { BSE } \\
\text { National } 500\end{array}$ & $\begin{array}{l}\text { Shanghai SE } \\
\text { Composite Index }\end{array}$ & $\begin{array}{l}\text { KOSPI } \\
\text { Composite Index }\end{array}$ & $\begin{array}{l}\text { FTSE/JSE } \\
\text { Allshare }\end{array}$ \\
\hline Country & Brazil & Russia & India & China & S Korea & South Africa \\
\hline Data available since & $1 / 3 / 1972$ & 9/1/1995 & 2/1/1999 & $1 / 2 / 1991$ & $12 / 31 / 1974$ & $6 / 1 / 1995$ \\
\hline Number of index constituent & 68 & 50 & 500 & 915 & 760 & 620 \\
\hline
\end{tabular}


Table 3. Pre-event and post-event CAARs for BRICKS

\begin{tabular}{llllllll}
\hline \multicolumn{2}{r}{ S Korea } & India & Brazil & China & Russia & S Africa & All \\
\hline \multicolumn{2}{l}{-20-+20 days event window: } & & & & & & \\
\hline CAARi & 0.0270 & 0.0128 & 0.0024 & 0.1054 & 0.0218 & -0.0370 & 0.0207 \\
CAARj & -0.0185 & -0.0427 & 0.0040 & -0.0152 & 0.0144 & 0.0162 & -0.0172 \\
SCAARi & 6.8605 & 2.8772 & 0.5249 & 11.2736 & 2.6653 & -6.2005 & 9.5379 \\
SCAARj & -4.8482 & -10.3331 & 0.7806 & -1.6589 & 1.3147 & 2.6656 & -7.6558 \\
\hline -1-+1 days event window: & & & & & & \\
\hline AAR-1 & 0.0145 & -0.0071 & 0.0158 & 0.0247 & 0.0162 & 0.0084 & 0.0103 \\
AAR0 & 0.0108 & -0.0054 & 0.0206 & 0.0084 & 0.0158 & 0.0092 & 0.0086 \\
AAR+1 & -0.0039 & 0.0022 & 0.0047 & 0.0187 & -0.0068 & 0.0063 & 0.0006 \\
CAAR (3) & 0.0215 & -0.0104 & 0.0412 & 0.0518 & 0.0252 & 0.0239 & 0.0195 \\
\hline
\end{tabular}

Table 4. Pre and post event CAR results for the sample companies in BRICKS

\begin{tabular}{|c|c|c|c|c|c|c|c|c|c|}
\hline Countries & $\begin{array}{l}\text { Total } \\
\text { number } \\
\text { of } \\
\text { companie } \\
\text { s }\end{array}$ & $\begin{array}{l}\text { Abnorma } \\
\text { I } \\
\text { Pre-event } \\
\text { Return }\end{array}$ & $\begin{array}{l}\% \\
\text { Abnorma } \\
\text { I } \\
\text { Pre-event } \\
\text { Return }\end{array}$ & $\begin{array}{l}\text { Abnorma } \\
\text { I } \\
\text { Post-even } \\
\text { t } \\
\text { Return }\end{array}$ & $\begin{array}{l}\% \\
\text { Abnorma } \\
1 \\
\text { Post-even } \\
\text { t Return }\end{array}$ & $\begin{array}{l}\text { Positive } \\
\text { Pre-event } \\
\text { Abnorma } \\
\text { I } \\
\text { Return }\end{array}$ & $\begin{array}{l}\% \\
\text { Positive } \\
\text { Pre-event } \\
\text { Abnorma } \\
\text { I } \\
\text { Return }\end{array}$ & $\begin{array}{l}\text { Positive } \\
\text { Post-even } \\
\text { t } \\
\text { Abnorma } \\
\text { I } \\
\text { Return }\end{array}$ & $\begin{array}{l}\% \\
\text { Positive } \\
\text { Post-even } \\
\text { t } \\
\text { Abnorma } \\
\text { I } \\
\text { Return } \\
\end{array}$ \\
\hline Brazil & 26 & 14 & 53.85 & 13 & 50.00 & 6 & 42.85 & 5 & 38.45 \\
\hline Russia & 6 & 2 & 33.33 & 3 & 50.00 & 1 & 50 & 2 & 66.67 \\
\hline India & 44 & 24 & 54.55 & 20 & 45.45 & 12 & 50 & 6 & 30 \\
\hline China & 11 & 6 & 54.55 & 9 & 81.82 & 6 & 100 & 5 & 55.55 \\
\hline $\begin{array}{l}\text { South } \\
\text { Korea }\end{array}$ & 113 & 52 & 46.02 & 55 & 48.67 & 26 & 50 & 24 & 43.63 \\
\hline $\begin{array}{l}\text { South } \\
\text { Africa }\end{array}$ & 14 & 7 & 50.00 & 6 & 42.86 & 3 & 42.85 & 5 & 83.33 \\
\hline Total & 214 & 105 & 49.07 & 106 & 49.53 & 54 & 51.42 & 47 & 44.33 \\
\hline
\end{tabular}

Table 5. Pre and post event stock characteristics for sample companies in BRICKS

\begin{tabular}{|c|c|c|c|c|}
\hline Country/Change & $\begin{array}{l}\text { Number of companies } \\
\text { showing significant } \\
\text { changes in Daily } \\
\text { Trading Volumes }\end{array}$ & $\begin{array}{l}\text { Number of companies } \\
\text { showing significant } \\
\text { changes in Daily } \\
\text { Returns volatility } \\
\end{array}$ & $\begin{array}{l}\text { Number of companies } \\
\text { showing } \\
\text { Daily } \\
\text { volatility }\end{array}$ & $\begin{array}{l}\text { Number of companies } \\
\text { exhibiting } \\
\text { significantly different } \\
\text { ACFs }\end{array}$ \\
\hline Brazil (26) & 0 & 26 & 26 & 0 \\
\hline Russia (6) & 0 & 6 & 6 & 0 \\
\hline India (42) & 0 & 37 & 35 & 4 \\
\hline China (11) & 0 & 11 & 11 & 0 \\
\hline South Korea (112) & 0 & 108 & 108 & 2 \\
\hline South Africa (14) & 0 & 14 & 14 & 0 \\
\hline
\end{tabular}

Table 6. Impact of mode of M\&A financing on pre and post event CAAR values for BRICKS

\begin{tabular}{llll}
\hline & Cash & Stock & Cash, Stock \&Others \\
\hline CAARi & -0.0035 & 0.0181 & 0.0682 \\
CAARj & -0.0159 & 0.0122 & 0.0018 \\
SCAARi & -0.8585 & 3.9033 & 4.8160 \\
SCAARj & -3.8249 & 3.0451 & 0.1268 \\
AAR0 & 0.0166 & 0.0080 & 0.0575 \\
AAR+1 & -0.0052 & 0.0088 & -0.0075 \\
CAAR(3) & 0.0305 & 0.0238 & 0.0994 \\
\hline
\end{tabular}




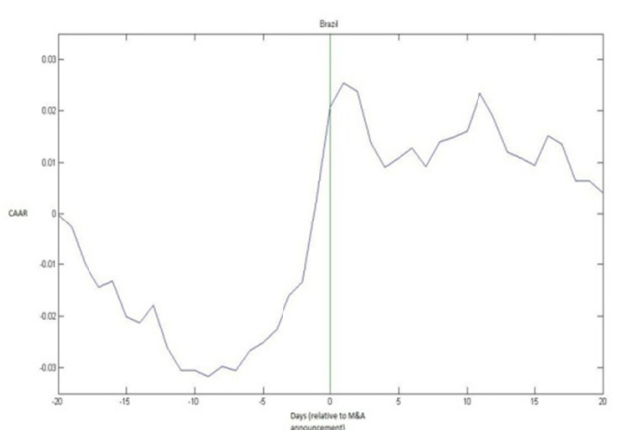

Brazil
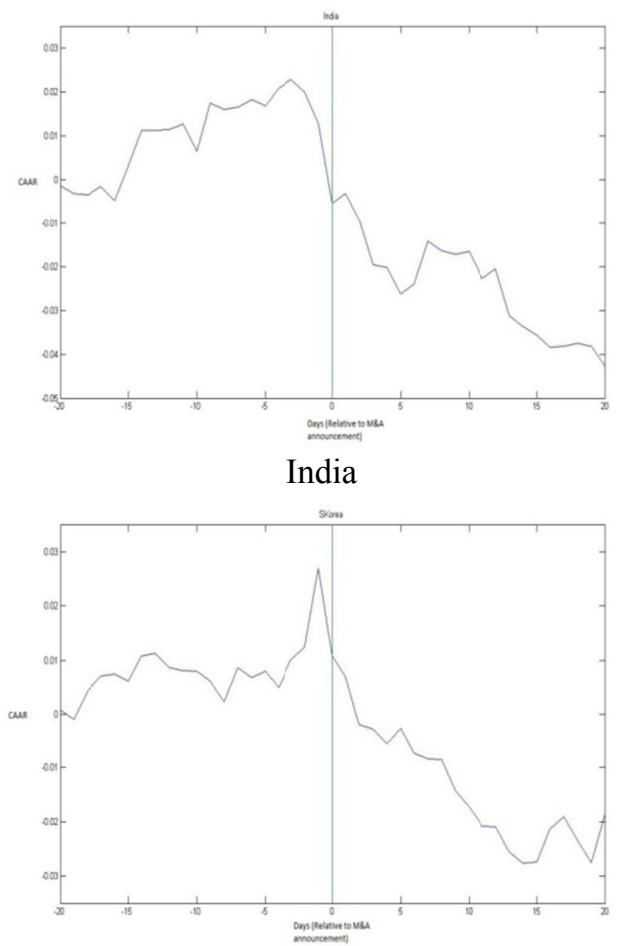

South Korea

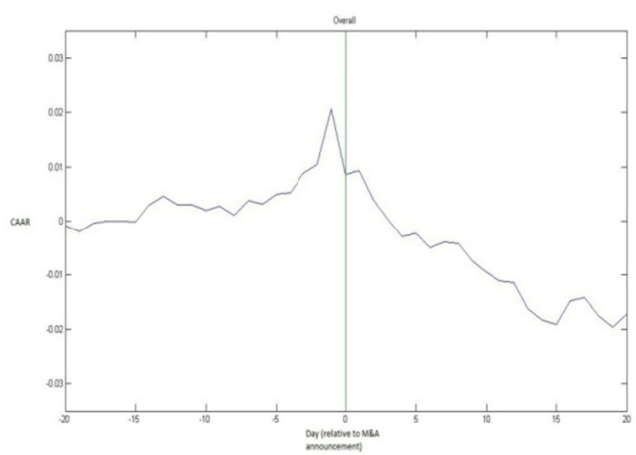

Aggregate

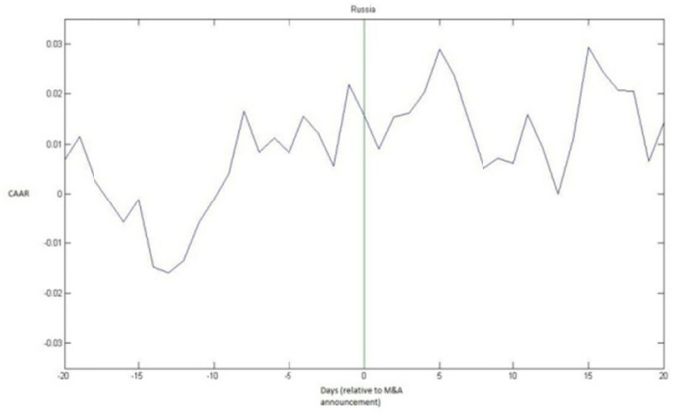

Russia

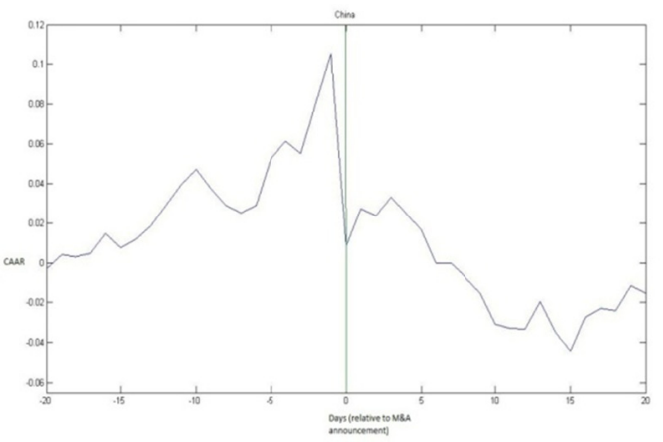

China

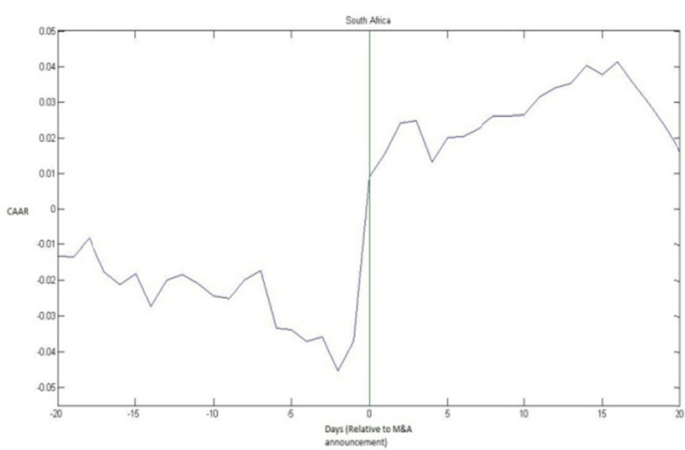

South Africa

Figure 1. Graphical depiction of CAAR values for sample countries as well as on aggregate basis

Note: The days relative to the M\&A date are represented on the $\mathrm{X}$-axis while CAAR values are depicted on the Y-axis. 


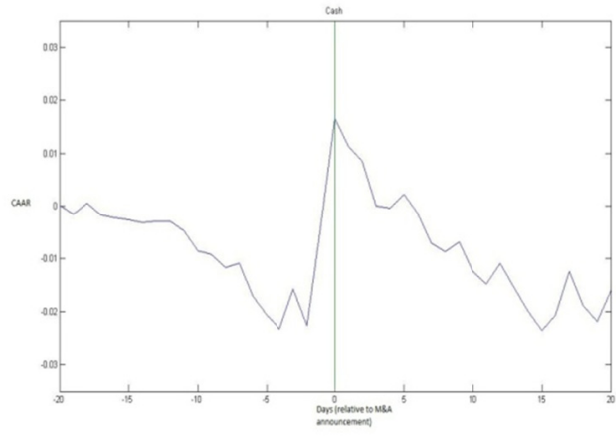

Cash financed

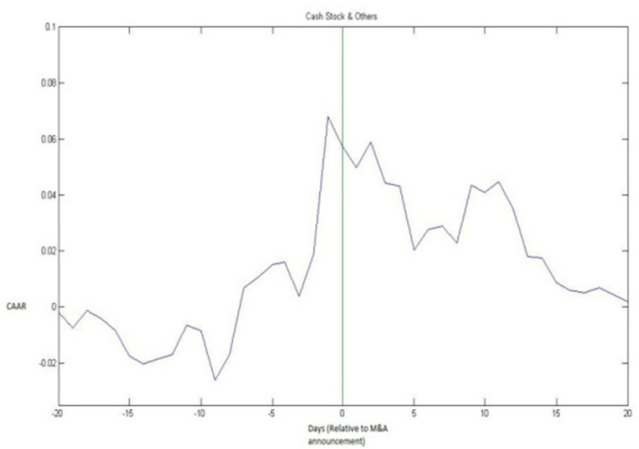

Financed through cash, stock and others

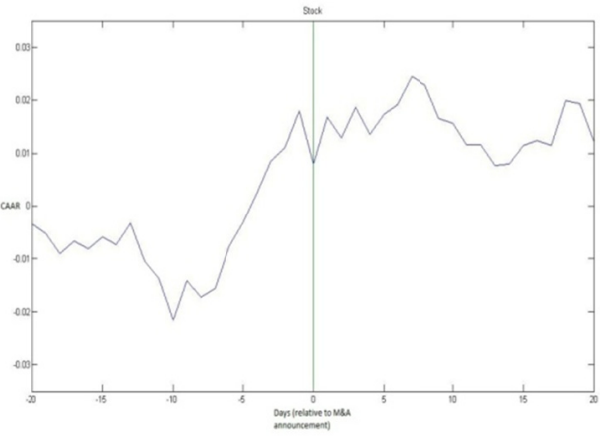

Stock financed

Figure 2. Graphical depiction at aggregate level of CAAR results for portfolios formed on basis of method of payment

Note: The days relative to the M\&A date are represented on the $\mathrm{X}$-axis while CAAR values are depicted on the Y-axis. 